\title{
P362: Biomedical waste in hospital: the case of maternity Issaka Gazobi and national hospitals of Niamey and Lamorde
}

\author{
H Djibo $^{1 *}$, M Kamaye $^{2}$, A Baden $^{3}$ \\ From 2nd International Conference on Prevention and Infection Control (ICPIC 2013) \\ Geneva, Switzerland. 25-28 June 2013
}

\section{Objectives}

To study the knowledge, attitudes and practices ofmedical waste management in health in Niger.

\section{Methods}

Preliminary prospective cross-sectional study, conducted over a period of 5 months and 10 days with an observation of the types of medical waste and an analysis of the knowledge and practices of 125 officers from three clinics in Niger. In total there were identified and interviewed in the Maternity Hospital and Issaka Gazobi National Niamey and Lamordé: 40 officials commonly called 'major' service, 61 laborers, 21 operating assistants [BH1], and 3 hygiene and sanitation technicians.

\section{Results}

It showed that the composition of medical waste is almost the same in three institutions. Characteristics of the wasteneedles, syringes, vials of injectable ampoules, gloves, pouches blood, urine bags, tubes, cotton, gauze, plaster, human organ, expired products, pharmaceutical and chemicalwastetotaled $49.60 \%$ of the residues services produced by the study. Knowledge of risks associated with medical waste: $92 \%$ are aware of the risks associated with mismanagement of medical waste and $64.8 \%$ of agent shave more than 5 years in their current position held, $70 \%$ of the 'majors' service state medical waste not undergo any treatment in the service and that the three health produce a total23.77tons per week or about 1236.04 tonnes of waste per year.

'Department of Public Health, Faculty of Health Sciences, University of Niamey, Niamey, Niger

Full list of author information is available at the end of the article

\section{Conclusion}

The need to strengthen the process of medical waste management in the health facilities.

\section{Disclosure of interest}

None declared.

\section{Author details}

'Department of Public Health, Faculty of Health Sciences, University of Niamey, Niamey, Niger. ${ }^{2}$ Control Unit Health Sector against STI / HIV / AIDS / Department of Public Health, Niamey, Niger. ${ }^{3}$ National Hospital of Niamey, Niamey, Niger.

Published: 20 June 2013

\section{doi:10.1186/2047-2994-2-S1-P362}

Cite this article as: Dijbo et al:: P362: Biomedical waste in hospital: the case of maternity Issaka Gazobi and national hospitals of Niamey and Lamorde. Antimicrobial Resistance and Infection Control 2013 2(Suppl 1): P362.

Submit your next manuscript to BioMed Central and take full advantage of:

- Convenient online submission

- Thorough peer review

- No space constraints or color figure charges

- Immediate publication on acceptance

- Inclusion in PubMed, CAS, Scopus and Google Scholar

- Research which is freely available for redistribution

\section{Biomed Central}

